\title{
MicroRNAs in Acute Myeloid Leukemia and Other Blood Disorders
}

\author{
Yao Yuan, ${ }^{1}$ Siddha Kasar, ${ }^{1}$ Chingiz Underbayev, ${ }^{1}$ \\ Sindhuri Prakash, ${ }^{1}$ and Elizabeth Raveche ${ }^{1,2}$ \\ ${ }^{1}$ New Jersey Medical School, Newark, NJ 08731, USA \\ ${ }^{2}$ Pathology and Laboratory Medicine, New Jersey Medical School, MSB C512, Newark, NJ 07103, USA
}

Correspondence should be addressed to Elizabeth Raveche, raveches@umdnj.edu

Received 6 March 2012; Accepted 17 April 2012

Academic Editor: Michael Danilenko

Copyright (C) 2012 Yao Yuan et al. This is an open access article distributed under the Creative Commons Attribution License, which permits unrestricted use, distribution, and reproduction in any medium, provided the original work is properly cited.

\begin{abstract}
Common blood disorders include hematopoietic cell malignancies or leukemias and plasma cell dyscrasia, all of which have associated microRNA abnormalities. In this paper, we discuss several leukemias including acute myeloid leukemia (AML) and chronic lymphocytic leukemia (CLL) and identify altered microRNAs and their targets. Immune disorders with altered blood levels of antibodies include autoimmune disorders, such as systemic lupus erythematosus (SLE) with associated anti-self-autoantibodies and immunoglobulin A nephropathy (IgAN) also have related microRNA abnormalities. The alterations in microRNAs may serve as therapeutic targets in these blood disorders.
\end{abstract}

\section{Introduction}

MicroRNAs are small (20-22 nt), evolutionarily conserved, noncoding single-stranded RNAs discovered in the 1990s $[1,2]$, functioning to target $3^{\prime}$ untranslated region (UTR) of mRNAs in antisense sequence specific way and regulate genes posttranscriptionally for degradation or translation suppression. MicroRNAs target $1-3 \%$ of all eukaryotic genes yet regulating $\sim 30 \%$ of protein-coding genes [3]. The miRNAs are first transcribed by RNA polymerase II in the nucleus as large primary transcript (pri-miRNA) [4], either from independent genes or from clustered genes encoding several miRNAs [5] and further processed into $\sim 70 \mathrm{nt}$ pre-miRNA with hairpin structure by Drosha, a RNase III type endonuclease (RN3) in the nucleus. Alternatively, in the nucleus, a small class of "mintron" without the stem-loop and the flanking single-strand structure as in pri-miRNA required for Drosha processing, could be generated by passing Drosha-dependent pathway [6]. In the cytoplasm, $\sim 20 \mathrm{bp}$ miRNA/miRNA* duplex are generated by Dicer, another RN3 endonuclease. One of the miRNA duplex strands is further incorporated into protein-RNA complex called RNAinduced silencing complex (RISC), although in some cases, both arms of the pre-miRNA hairpin could generate mature
miRNAs [7-9]. miRNAs interact with target mRNA by sequence complementarity, and in perfect base pairing usually triggers endonucleolytic mRNA cleavage [10]; however, in most situations, such base pairing is imperfect, resulting in translational suppression. The key component of this RISC machinery is Ago protein family (Ago 1-4), but only Ago 2 is known to have the catalytic enzyme function $[11,12]$. Besides Ago proteins, GW182 protein is also recruited to the RISC complex and together localize in cytoplasmic foci called processing bodies (P bodies or GW bodies), where mRNA is sequestered from being translated [13-16]. There are different experimental and bioinformatics approaches to predict miRNA targets. At a minimum, the precise matching to $3^{\prime}$ UTR of mRNA in multiple copies should be within the first 2-8 bases from the $5^{\prime}$ end of the mature miRNA, called the "seed region" [17-20]. To date, over 2000 human miRNAs have been annotated in the Sanger miRBASE (Release 18, http://www.mirbase.org/ cgi-bin/browse.pl?org=hsa). The miRNA network is highly re dundant, since a single miRNA may have multiple target mRNAs, and in turn, a single mRNA could be targeted by many miRNAs [21]. Various miRNAs have been shown to be involved in a myriad of cellular processes including 
differentiation, metabolism, apoptosis, and development [22]. Physiologically, and pathologically, miRNAs have been reported to play roles in cancers, inflammatory responses, diabetes, and autoimmunity $[23,24]$.

\section{MicroRNAs in Hematopoietic Stem Cells}

Multiple evidence suggest that microRNAs play a significant role in the posttranscriptional genetic regulation in stem and progenitor cells. They are involved in a number of hematological malignancies such as acute lymphoblastic leukemia, acute myeloid leukemia, chronic lymphocytic leukemia, chronic myelogenous leukemia, diffuse large-B-cell lymphoma, and others [25]. Therefore, miRNA profiling is critical in order to distinguish stem cells of the different origins, developmental stages, and genetic conditions [26]. Furthermore, it can help classify cancer cell samples and develop appropriate therapeutic strategies [27]. Recent studies have demonstrated a causative role for miRNAs in malignant diseases development in the hematopoietic system. For instance, overexpression of miR-155 or miR-29a in the mouse hematopoietic system leads to a myeloproliferative disorder [28] or leukemia [29], respectively. On the other hand, tumor suppressor miRNAs such as miR-15a/16-1 are found to be deleted in a subset of lymphomas [30] and have been shown to cause chronic lymphocytic leukemia in mice [31, 32]. MicroRNA-125b has been demonstrated to cause pathological myeloid cells expansion in a dose-dependant manner [33], and miR-155 is known to induce polyclonal expansion followed by B-cell malignancy development [34]. In another study on human umbilical cord blood, two particular miRNAs-hsa-miR-520h and hsa-miR-526b*- levels appeared to be elevated. Interestingly, ABCG2, an important factor of stem cells maintenance, is a known target of hsamiR-520h [35].

\section{MicroRNAs in the Immune System}

Proper regulation of immune response is critical in preventing immunopathology and autoimmune disorders. Studies have implicated important functions of miRNA on hematopoietic development as well as innate and adaptive immune responses. Toll-like receptor (TLR) signaling leads to transcriptional activation of a large class of proinflammatory cytokines as well as multiple miRNAs. For example, miR146a and miR-155 have been shown to be upregulated upon exposure to LPS in the monocytic leukemia cell line THP1. More importantly, two key components of TLR4 signaling pathway, TRAF6 and IRAK1 have been verified to be targets for miR-146a [36]. This study for the first time profiled the miRNAs alterations in TLR signaling and proposed the miRNAs as negative regulators of TLR activation. MiR-155 is another well-studied microRNA reported to be activated by several TLR pathways $[36,37]$, and its negative regulatory role during TLR-mediated activation has also been addressed $[38,39]$. More interestingly, IL-10 is shown to inhibit TLR-induced miR-155 [40]. To understand global miRNAs' importance in $\mathrm{B}$ and $\mathrm{T}$ development, studies were performed in which knocking out Dicer at different stages of $\mathrm{B}$ and $\mathrm{T}$ development resulted in blockage of further differentiation [41-43]. In addition, miR-155 has been found to be one of the most important miRNAs in both $\mathrm{B}$ and $\mathrm{T}$ cells as well as antigen presentation by dendritic cells (DCs) and is required for normal germinal center (GC) response [44, 45], B-cell class switching [46], Th1/Th2 polarization, and Treg development both in the thymus and peripheral [47].

\section{MicroRNA in Autoimmune Diseases}

Considering the importance of miRNAs in the immune system raises the question whether or not there is direct link between miRNAs abnormalities and immune disorders or autoimmune diseases. Interestingly, the discovery in 2002 of GW bodies (GWBs), where miRNA-mRNA reside for degradation was from serum from an autoimmune patient with motor and sensory neuropathy [48]. Subsequently, antiGWB autoantibodies in the serum have been identified from patients with various autoimmune disorders [49], indicating an involvement of general miRNA pathway and autoantibody production. Dysregulated miRNA expression has been associated with autoimmunity, for example, miR-146a was underexpressed in PBMC from SLE patients when compared with healthy control. The study further showed that miR$146 \mathrm{a}$ is a negative regulator of type I interferon (IFN) pathway by targeting interferon regulatory factor (IRF) 5 and signal transducers and activators of transcription (STAT) 1 , thus the decrease in miR-146a may contribute to the increased type I IFN signaling pathway observed in SLE [50]. A recent study in murine models (MRL-lpr, C57BL/6lpr, and NZB/NZW F1) of SLE using a combination of microarray and real-time RT-PCR approaches, Dai et al. identified that miR-182-96-183 cluster, miR-31, and miR-155 are among those consistently upregulated miRNAs across different genetic background strains of mice [51]. In addition to important contribution of miR-155 to physiological immune response, its activity in autoimmune circumstances was also investigated. A murine experimental autoimmune encephalomyelitis (EAE) model with mir-155 ${ }^{-1-}$ was shown to be resistant to EAE pathology. Thus, unregulated miR-155 may be a link between inflammation and cancer via inducing a high proliferation rate resulting in increased mutations [52]. The miR-17-92 cluster locating in human chromosome $13 \mathrm{q} 31$ is known as an onco-miR, and this genomic region is often amplified in lymphomas and other cancer, and the mature miR-17-92 expression is highly elevated in malignant cells [27, 53-55]. Results showed that miR-17-92 targets phosphatase and tensin homolog (PTEN, tumor suppressor) and Bim (proapoptotic molecule) mRNA directly resulting in lymphoproliferative and autoimmune diseases [56]. In a current study from our lab on microRNA abnormalities in NZB/NZW F1 lupus model by using type I and type III interferons (IFN- $\alpha$ and IFN- $\lambda$ ) as exogenous disease accelerators, we identified upregulation of several microRNAs correlated to disease severity, yet not with the IFN treatment. MiR-15a was one of the most significant elevated microRNAs as autoimmunity developed in these mice and the level of splenic miR-15a was correlated to the level of anti-dsDNA IgG, in addition, the cellular level of miR-15a 
was also reflected in the plasma (manuscript accepted for publication).

\section{MicroRNAs in Hyperimmunoglobulinemias}

Multiple myeloma (MM) is characterized by a clonal expansion of plasma B cells in the bone marrow or in extramedullary sites which results in high levels of monoclonal immunoglobulins in the serum [57]. Cytogenetic abnormalities are present in many MM cases, characterized by either hyperdiploidy with the presence of trisomies of odd chromosomes or nonhyperdiploidy with chromosomal aberrations and translocations involving the IgH locus on chromosome 14. In addition to these advancements in understanding MM pathogenesis, studies on the role of microRNAs in recent years have shown them to be key players in MM development not only in the sustenance of malignant cells but also in the initiation of malignancy due to methylation of microRNAs that function as tumor suppressors. Studies investigating microRNAs in MM began in 2007 with the discovery that interleukin 6 (IL-6) indirectly induces the transcription of miR-21 through signal transducer and activator of transcription 3 (STAT3) transcription in the human myeloma cells line. The same upstream enhancer controls miR-21 and STAT3 transcription, and STAT3 controls the transcription of survivin, Bcl2, and Mcl-1. Thus, Stat 3 exerts its antiapoptotic affect through the induction of miR-21 [58]. A microRNA microarray analysis in 20 myeloma samples revealed that miR-335 and miR-342-3p were upregulated and may be involved in plasma cell homing and other interactions in the bone marrow [59]. Subsequent studies uncovered various microRNAs that are key players in MM. For example, miR-106b-25 cluster, miR-18la/b, and miR32 target a histone acetyltransferase, P300/CBP-associated factor (PCAF) that reversibly acetylates transcriptional regulators including p53, thus accounting for the low levels of PCAF observed in MM cells. Also miR-17-92 downregulates Bim, a proapoptotic molecule, and miR-19a/b target SOCS1 , a silencer of the STAT3, thus enhancing the oncogenicity of MM cells $[60,61]$. As seen in CLL, miR-15a/16-1 is seen to be downregulated in multiple myeloma [62]. Normally encoded within the DLEU2, a gene frequently deleted in lymphocytic leukemia, miR-15a/16-1 activity is central to the antiproliferative activity of DLEU2 [63], as miR-15a/16-1 inhibits cyclinD1, cyclinD2, and CDC25a [62]. Also, several microRNAs have been seen to target the p53 gene. For example, miR-25 and miR-30d are increased in MM and target the $3^{\prime}$ UTR of the p53 gene [64]. Also, MM cells have low levels of miR-192, miR-194, and miR-215 which targets MDM2, a p53 antagonist, thereby lowering p53 levels and increasing oncogenic potential [65]. Moreover, the promoter of miR-34b/c, a transcriptional target of $\mathrm{p} 53$ was found to be hypermethylated and thus inactivated in multiple myeloma cell lines. Such epigenetic modifications are observed to be causal in other microRNAs as well. Hypermethylation of the promoters of various tumor suppressors such as miR-124-1 (a target of CDK6) [66], miR-203 (a target of cyclic-responsive element-binding protein which increases proliferation) [67], and miR-29b (a target of Mcl-1 which antagonizes IL-6) increase the tumorigenicity of myeloma cells [68]. Extranodal marginal zone lymphomas are most associated with mucosal-associated lymphoid tissue (MALT) and are characterized by clonal proliferation of plasma cells that produce the immunoglobulin A isotype. Investigations involving microRNAs have found the miR-203 promoter to be hypermethylated in samples of gastric lymphoma, and this microRNA targets the c-abll oncogene, thus enabling tumor growth and proliferation [69]. In addition, miR-150 and miR-155 were upregulated, while miR-184, miR-205 and $\mathrm{miR}-200 \mathrm{a} / \mathrm{b} / \mathrm{c}$ (which targets cyclin E2) were downregulated [70]. In another hyperimmunoglobulin disorder, Immunoglobulin A nephropathy (IgAN) is characterized by the deposition of immune complexes in the kidney mesenchyme causing renal injury and usually coincides with mucosal infections [57]. These immune complexes are composed of IgA1 molecules that are galactose-deficient, causing a conformational change in the molecule, and autoantibodies (IgA or $\mathrm{IgG}$ ) form to its exposed epitopes [71]. Since miR-155 and miR-146 are involved in B lymphocyte development, their levels were examined in 43 IgAN biopsy specimens and urine samples. The results showed that miR-146 and miR-155 were high in IgAN biopsy and urine sediment, suggesting their role in IgAN pathogenesis [72].

\section{MicroRNAs in Acute Myeloid Leukemia (AML)}

MicroRNAs (miRNAs) have been well studied in various cancers including leukemias [73, 74]. Acute myeloid leukemia (AML) is a hematopoietic progenitor cell-originated malignant disorder affecting the myeloid lineage, which could be classified into subtypes based on the differentiation stages of the malignant cells found in peripheral blood and in bone marrow [75]. Among various symptoms and manifestations identified in association with AML, one of the most common characteristics involved in $\sim 50 \%$ of AML patients is a group of cytogenetic abnormalities, which is considered to be contributing to the disease heterogeneity and with prognostic significance [76]. Other AML patients without detectable chromosomal abnormalities may display mutations or dysregulations in specific genes, a signature ubiquitously found in cancers [77-79]. MicroRNA signatures in AML have been sought, and many groups of researchers performed largescale profiling of miRNA expression in different populations of AML patients. In the first study where AML patient samples were compared to acute lymphoblastic leukemia (ALL), both groups with similar chromosomal alterations, 27 miRNAs were reported to be different between the two groups [80]. Importantly, miR-146a was inversely correlated to overall survival in both AML and ALL [81]. However, these studies focused on miRNA profile distinguishing AML from ALL, which was not sufficient for understanding the abnormalities of miRNAs expression exclusive to AML.

Another study compared 122 AML samples to CD34+ cells from 10 normal controls. Among the 122 AML samples, 60 cases were untreated and 54 relapsed or refractory [82]. By microarray profiling, 26 microRNAs were downregulated 
in AML samples. Several of these downregulated miRNAs in AML were also underexpressed in mature myeloid cells suggesting that miRNAs related to the differentiation patterns in AML (miR-126, miR-130a, miR-93, miR-125a, and miR146). In correlating cytogenetic abnormalities with miRNA expression, 14 downregulated and 8 upregulated miRNAs were associated with 11q23 translocation versus all other AML, including the downregulation of miR-196 and miR$15 \mathrm{a}$, and overexpression of miR-21 in $t(6 ; 11)$ with worse prognosis [82]. In AML patients $(n=36)$ achieving complete remission the levels of miR-15a/16 were upregulated. Subsequently, in 2 patients in which relapse occurred, miR-15a decreased. All-trans retinoic acid (ATRA) in vitro treatment in AML cell lines and primary leukemic cells induced miR$15 \mathrm{a} / 16$ upregulation, in addition, miR-15a/16 enhanced the effects of ATRA inducing leukemic cell differentiation [83]. Despite the poor overall survival of these AML patients, the study showed several associations between miRNA expression and the outcome of patients, especially the overexpression of miR-199a and miR-191, identified in AML with trisomy 8 and associated with poor outcome. This study was the first to identify the distinct miRNAs profile between AML patients and normal control, and the subsets of miRNAs related to cytogenetic groups and disease outcome [82].

Almost at the same time, a study with 215 heterogeneous AML samples was performed to demonstrate the signatures of miRNAs expression in cytogenetic and molecular subtypes [84]. A group of upregulated miRNAs were prominent in $t(15 ; 17)$ cases. In contrast, $t(8 ; 21)$ was characterized by downregulated miRNA alterations, for example, tumor suppressor let-7. In molecular subgroups of AML, nucleophosmin (NPM1) mutations, which represent the most common molecular abnormality in AML, are associated with overexpression of homeobox genes $(H O X)$ [85]. Upregulation of miR-10a, miR-10b, miR-196a and miR-196b, was identified in AML carrying NPM1 mutations, and these miRNAs were located within the HOX genes. Although miR-196a directly targets $H O X B 8$ mRNA [86], the upregulated miR$196 \mathrm{a}$ in this AML subgroups may represent a breakage in the regulation loop between miRNAs and HOX genes [84]. Consistent with other studies, miR-155 was significantly upregulated in AMLs with internal tandem duplications of Flt3(FLT3-ITD), corroborating the oncogenic effect of miR155 in myeloid cells in addition to such effects in lymphoid lineages $[84,87,88]$. In comparing AML to normal CD34+ cells, upregulation of miR-21 in AMLs was found, consistent with other studies and further strengthening the importance of miR-21 in AML $[82,84]$.

Interestingly, in an analysis of AML subgroups the $t(8 ; 21)$ and inv $(16)$ were grouped together by miRNA profile, supporting the notion that both subgroups belong to corebinding factor (CBF) AMLs, suggesting some common pathways shared by CBF-AMLs [89]. Overexpression of miR-224, miR-368, and miR-382 was restricted to the $t(15 ; 17)$ samples, while miR-17-92 cluster was overexpressed exclusively in mixed-lineage leukemia (MLL) rearrangements [89]. In addition, in a study of 100 AMLs, comparing leukemic samples to normal bone marrow, miR-155 and miR-181a were upregulated [90]. MiR-181a has been reported to target p27 Kip1 in AML cell lines, resulting in an abrogation of 1 , 25-dihydroxyvitamin D3 (1,25D) induced differentiation in AML cell lines [91]. A recent study classified AML cases into favorable, moderate, and poor as the predicted outcome according to the karyotype. MiR-181a high expression was suggested to be associated with better-risk groups suggesting a potential therapeutic approach involving manipulation of miR-181a level in AML patients. In contrast to elevated miR181a as favorable prognostic factor, miR-155 upregulation predicts poor prognosis in AML [92].

\section{MicroRNAs in Chronic Lymphocytic Leukemia (CLL)}

CLL is characterized by the accumulation of malignant B1 cells $\left(\mathrm{CD}^{+} \mathrm{CD} 19^{+} \mathrm{CD} 20^{\text {dull }} \mathrm{CD} 23^{+} \mathrm{IgM}^{\text {dull }}\right)$ in peripheral lymphoid organs, bone marrow, and peripheral blood [93]. It accounts for $30 \%$ of all leukemias in the Western world, making it the most common lymphoid malignancy with mainly elderly with disease. CLL is broadly classified into aggressive (Zap70 ${ }^{\text {hi }}$-unmutated $\operatorname{IgH}$ ) and indolent (Zap70 ${ }^{\text {low }}$-mutated IgH) [94]. CLL cells have genomic instability, chromosomal alterations and have several characteristic genetic abnormalities. Prominent among them are 11q23 deletions (ATM; miR-34b/c cluster), trisomy 12 (increased MDM2), 17p deletion (TP53), and 13q14 deletions (miR15a/16-1) [95]. Dysregulation of several microRNAs like miR-15a/16-1, miR-34 cluster, miR-155, miR-29, and miR$181 \mathrm{~b}$ has been implicated in the pathogenesis of CLL. The most common genetic abnormality in CLL patients is the deletion of 13 q14 region (50-60\% of CLL cases) that encodes a crucial microRNA locus, $m i R-15 a / 16-1$ [30, 96]. Decreased miR-15a/16-1 confers a growth advantage as these microRNAs target key cell cycle regulatory and antiapoptotic proteins such as cyclin D1 and $\mathrm{Bcl} 2[97,98]$. It is interesting to note that NZB mice (spontaneously occurring mouse model of CLL) also exhibit a 50\% reduction in the level of miR-15a/16-1, that is associated with a point mutation and deletion in the $3^{\prime}$ flanking region of miR-16-1 [99]. Moreover targeted deletion of the miR-15a/16-1 locus or a larger surrounding minimal deleted region (MDR) led to the development of CLL in mice, further confirming the tumor suppressor function of this locus [32]. Other microRNAs are abnormal in CLL including miR-29 and miR-181, which target Tcl1, a gene that is highly elevated in aggressive CLL [100]. MiR-29 expression is decreased in aggressive CLL, while it is increased in indolent CLL as compared to normal volunteers $[100,101]$. Thus, the same microRNA can function as both an oncogene and as a tumor suppressor in CLL. MiR-34a/b/c is decreased in patients with $11 \mathrm{q}$ deletions. Normally, upon transactivation by TP53, miR-34 expression would result in decreased Zap70 [102]. MiR-34a has also been shown to target E2F1 and B-Myb oncogenes in CLL as well as AML [103]. MiR-155, miR-150, and miR-21 expression is increased in B-CLL cells as compared to normal $B$ cells $[23,104]$. Increased miR-155 levels are associated with increased Zap70 expression and faster progression. $\mathrm{v}-\mathrm{Myb}$ is 
TABLE 1: MiR-15/107 group involvement in common blood disorders ${ }^{\S}$.

\begin{tabular}{|c|c|c|c|}
\hline Blood disorders & MiR-15/107 group alterations & Abnormalities associated & Effects of miRNAs \\
\hline AML & $\begin{array}{l}\text { MiR-15a/16 decreased in } t(11 \mathrm{q} 23) \mathrm{AML} \\
\text { patients [82], elevated in patients with } \\
\text { complete remission, and decreased with } \\
\text { relapse [83] }\end{array}$ & & $\begin{array}{l}\text { MiR-15a/16 enhanced ATRA effects } \\
\text { inducing AML cell differentiation [83] }\end{array}$ \\
\hline APL & $\begin{array}{l}\text { MiR-15a/16 upregulation and miR-107 } \\
\text { downregulation in a cohort of APL } \\
\text { patients [135] }\end{array}$ & & $\begin{array}{l}\text { Patients showed increased miR-15/107 } \\
\text { during remission, and miR-15/107 } \\
\text { upregulation was induced by ATRA in vitro } \\
\text { in APL cells [135] }\end{array}$ \\
\hline \multirow{3}{*}{ CLL } & $\begin{array}{l}\text { MiR-15a/16 underexpressed in CLL } \\
\text { patients with 13q14 deletion and NZB } \\
\text { mice (CLL model) }[96,99]\end{array}$ & $\begin{array}{l}\text { Uncontrolled B-1 cell } \\
\text { proliferation [97] }\end{array}$ & $\begin{array}{l}\text { Overexpression of miR-15a/16 in CLL } \\
\text { murine model resulted in exclusive } \\
\text { elimination of malignant B-1 cells [136] }\end{array}$ \\
\hline & $\begin{array}{l}\text { MiR-195 upregulation reported from a } \\
\text { study of } 9 \text { CLL patients compared to } \\
\text { normal controls [137] }\end{array}$ & & Not determined \\
\hline & $\begin{array}{l}\text { MiR-107 downregulated in CLL patients } \\
{[138]}\end{array}$ & & $\begin{array}{l}\text { Underexpression of miR-107 resulted in } \\
\text { overexpression of oncogenic PLAG-1 } \\
\text { protein }[138]\end{array}$ \\
\hline MM & $\begin{array}{l}\text { MiR-15a/16 decreased in MM patients } \\
{[62]}\end{array}$ & $\begin{array}{l}\text { Uncontrolled clonal plasma cell } \\
\text { proliferation and } \\
\text { proangiogenesis in bone marrow } \\
{[62]}\end{array}$ & $\begin{array}{l}\text { MiR- } 15 \mathrm{a} / 16 \text { targeted cell cycle regulators, } \\
\text { inhibited NF- } \kappa \mathrm{B} \text { pathway, and } \\
\text { downregulated proangiogenic genes }[62]\end{array}$ \\
\hline SLE & $\begin{array}{l}\text { miR-15a upregulated in spleen cells from } \\
\text { NZB/NZW F1 mice (SLE model), when } \\
\text { disease fully developed (manuscript } \\
\text { accepted for publication) }\end{array}$ & $\begin{array}{l}\text { Elevated autoreactive antibody } \\
\text { producing cells terminally } \\
\text { differentiated plasma cells }\end{array}$ & $\begin{array}{l}\text { MiR-15a enhanced plasma cell } \\
\text { differentiation }\end{array}$ \\
\hline
\end{tabular}

found to be elevated in CLL patients, and it stimulates the miR-155 host gene [105]. The oncogenic potential of miR155 is further supported by the development of B-cell malignancies in $\mathrm{E} \mu$-mmu-miR-155 transgenic mice [34]. Using a poorly understood mechanism, microRNAs are secreted into body fluids such as serum and urine, and their levels can be used as noninvasive biomarkers for diagnosis and monitoring of cancer and various other diseases [106, 107]. In a recent, study it was shown that elevated miRNA levels in serum may offer early CLL detection and differentiation between Zap70 status [108]. The authors further concluded that increased expression of miR-150, miR-29a, miR-222, and miR-195 can be used as a highly sensitive diagnostic test for CLL.

\section{Conclusion}

In this paper, a variety of blood disorders were discussed in terms of microRNA abnormalities observed. One microRNA family of interest stood out as a potential regulator of cell fate (Table 1 and Figure 1). Recently, miR-15 family members (miR-15a/b, miR-16, miR-103, miR-107, miR-195, and miR497) have been grouped together due to their identical "AGCAGC" sequence at 5' end "seed region (nucleotides $2-7)$ " $[109,110]$, which offers this miRNA group various overlapping functions in gene-regulatory pathways and disease scenarios, especially in cancers. MiR-15/107 gene group could be upregulated by tumor suppressor p53 [102], altered by various cell stress [111-115], or inhibited by Myc [116, 117]. A broad spectrum of mRNAs is targeted by miR15/107, importantly, miR-15/16 paralogs regulate cell cycle via targeting of Cyclin D1 [97] and induce apoptosis via targeting of Bcl-2 [118], and miR-107 also induces cell cycle arrest [119]. The tight involvement of miR-15/107 in cell growth and cell fate control, and their upstream regulators, such as p53 and Myc, which by themselves are important players in tumorigenesis $[120,121]$, revealed critical mechanisms for abnormalities in cancer development, including leukemias. Indeed, all members from miR-15/107 group have been identified to be altered in various tumor cells [122-125]. Specifically, underexpression of miR-15a/16 as a result of deletion or mutation of mir-15a/16 loci has been linked to the pathogenesis of CLL $[96,99,118]$, similarly in AML and MM, where the downregulation of miR-15a/16 was associated with the loss of control for malignant cells differentiation and proliferation $[62,83]$. In contrast, in SLE which is characterized by elevated plasma cell differentiation contributing to increased autoantibody production [126, 127], splenic miR-15a was increased, and this was significantly correlated with autoantibody levels in lupus-like autoimmune mouse model (manuscript accepted for publication), suggesting a role of miR-15a upregulation in cell cycle arrest in order for plasma cell differentiation.

Future directions may be directed toward stem cell transplantation for many of these blood disorders. Cellular transplantation therapy holds a huge potential for a variety of 


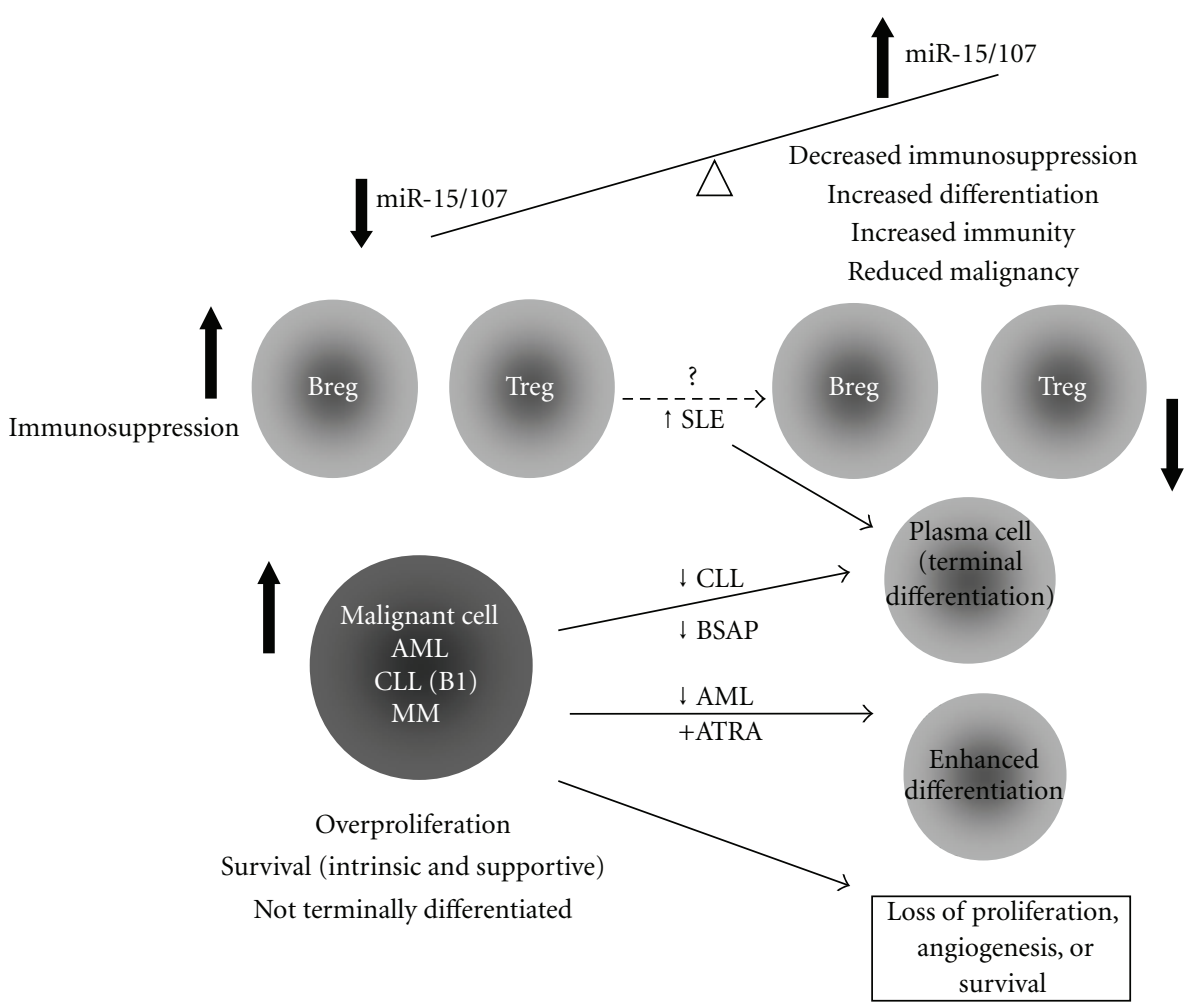

FIGURE 1: Schematic mechanism of miR-15/107 family alterations in hematopoietic disorders. Decreased expression of miR-15/107 family members is found in malignant cells from AML (acute myeloid leukemia), CLL (chronic lymphocytic leukemia), and MM (multiple myeloma) patients. The underexpression of miR-15/107 may also contribute to increased immunosuppressive regulatory B (Breg) and $\mathrm{T}$ cells (Treg), which further promote the expansion and survival of malignant cells. In contrast, with increased miR-15/107, there may be a loss of immunosuppression that leads to SLE (systemic lupus erythematosus) development and antitumor responses. In the therapeutically induced differentiated AML cells, and terminally differentiated B cells, plasma cells (with decreased B-cell-specific activator protein (BSAP), the negative regulator of miR-15a/16-1), miR-15/107 family members would be upregulated, leading to the loss of malignant potential and an increase in differentiation function (SLE).

degenerative, genetic, and malignant conditions treatment. Hematopoietic stem cell transplantation is the most widely used form of such a therapy, but many patients do not benefit from that because of the lack of a suitable HLAmatched donor [128]. In this sense, patient-specific autologous pluripotent stem cells generation would provide a great opportunity to combine gene therapy with autologous cell transplantation to treat different human conditions including hematological disorders such as AML. For this reason, robust protocols for the generation of safe autologous induced pluripotent stem (iPS) cells are strongly needed. To this end, microRNAs represent an attractive tool for both iPS generation efficiency enhancement and gene targeting approaches. It is known that expression of embryonic stem (ES) cell-specific microRNAs such as miR-294 promotes iPS cells induction from somatic cells [129]. Recently, it has even been demonstrated that the expression of miR-302/367 cluster can directly reprogram mouse and human somatic cells to a pluripotent stem cell state in the absence of the commonly used reprogramming factors [130]. Alternatively, inhibition of tissue-specific miRNAs would also enhance iPS generation, which has been confirmed by antisense silencing of a prodifferentiation let-7 miRNA [131]. Another application of microRNAs lies in promoting patient-specific iPS differentiation towards the required cell lineage, for example HSC expansion. MiR-145 has been shown to induce ES cell differentiation by inhibiting the expression of Sox2, Oct4, Klf4, and c-Myc, key reprogramming factors, and led to an increase of HSC number in vivo by more than 8 fold [132134]. Nevertheless, HSC expansion from iPS cells by means of microRNAs needs to be further developed. Hopefully, the recently achieved success in the production of iPS cells with the use of miRNAs will pave the way for successful in vitro expansion of HSCs with miRNAs.

\section{Abbreviations}

miRNA/miR: MicroRNA

AML: $\quad$ Acute myeloid leukemia

ALL: $\quad$ Acute lymphoblastic leukemia

CLL: Chronic lymphocytic leukemia

SLE: $\quad$ Systemic lupus erythematosus

IgAN: Immunoglobulin A nephropathy

MM: $\quad$ Multiple myeloma

TLR: Toll-like receptor

IFN: Interferon 


$\begin{array}{ll}\text { 3'UTR: } & \text { 3'untranslated region } \\ \text { NZB: } & \text { New Zealand black } \\ \text { ATRA: } & \text { All-trans retinoic acid } \\ \text { HOX: } & \text { Homeobox genes } \\ \text { NPM: } & \text { Nucleophosmin } \\ \text { FLT3-ITD: } & \text { Internal tandem duplications of Flt3 } \\ \text { CBF: } & \text { Core-binding factor } \\ \text { iPS cell: } & \text { Induced pluripotent stem cell } \\ \text { HSC: } & \text { Hematopoietic stem cells } \\ \text { ES cell: } & \text { Embryonic stem cells. }\end{array}$

\section{Acknowledgment}

This work was supported by NCI R01CA129826 (E. Raveche).

\section{References}

[1] R. C. Lee, R. L. Feinbaum, and V. Ambros, "The C. elegans heterochronic gene lin- 4 encodes small RNAs with antisense complementarity to lin-14," Cell, vol. 75, no. 5, pp. 843-854, 1993.

[2] B. Wightman, I. Ha, and G. Ruvkun, "Posttranscriptional regulation of the heterochronic gene lin-14 by lin- 4 mediates temporal pattern formation in C. elegans," Cell, vol. 75, no. 5, pp. 855-862, 1993.

[3] W. Filipowicz, S. N. Bhattacharyya, and N. Sonenberg, "Mechanisms of post-transcriptional regulation by microRNAs: are the answers in sight?" Nature Reviews Genetics, vol. 9, no. 2, pp. 102-114, 2008.

[4] V. N. Kim, "MicroRNA biogenesis: coordinated cropping and dicing," Nature Reviews Molecular Cell Biology, vol. 6, no. 5, pp. 376-385, 2005.

[5] M. Lagos-Quintana, R. Rauhut, W. Lendeckel, and T. Tuschl, "Identification of novel genes coding for small expressed RNAs," Science, vol. 294, no. 5543, pp. 853-858, 2001.

[6] J. G. Ruby, C. H. Jan, and D. P. Bartel, "Intronic microRNA precursors that bypass drosha processing," Nature, vol. 448, no. 7149, pp. 83-86, 2007.

[7] N. Bushati and S. M. Cohen, "MicroRNA functions," Annual Review of Cell and Developmental Biology, vol. 23, pp. 175205, 2007.

[8] T. M. Rana, "Illuminating the silence: understanding the structure and function of small RNAs," Nature Reviews Molecular Cell Biology, vol. 8, no. 1, pp. 23-36, 2007.

[9] T. Du and P. D. Zamore, "MicroPrimer: the biogenesis and function of microRNA," Development, vol. 132, no. 21, pp. 4645-4652, 2005.

[10] M. W. Jones-Rhoades, D. P. Bartel, and B. Bartel, "MicroRNAs and their regulatory roles in plants," Annual Review of Plant Biology, vol. 57, pp. 19-53, 2006.

[11] J. Liu, M. A. Carmell, F. V. Rivas et al., "Argonaute2 is the catalytic engine of mammalian RNAi," Science, vol. 305, no. 5689, pp. 1437-1441, 2004.

[12] G. Meister, M. Landthaler, A. Patkaniowska, Y. Dorsett, G. Teng, and T. Tuschl, "Human argonaute 2 mediates RNA cleavage targeted by miRNAs and siRNAs," Molecular Cell, vol. 15, no. 2, pp. 185-197, 2004.

[13] T. Eystathioy, A. Jakymiw, E. K. Chan, B. Séraphin, N. Cougot, and M. J. Fritzler, "The GW182 protein colocalizes with mRNA degradation associated proteins hDcp 1 and hLSm 4 in cytoplasmic GW bodies," RNA, vol. 9, no. 10, pp. 1171-1173, 2003.

[14] L. Ding and M. Han, "GW182 family proteins are crucial for microRNA-mediated gene silencing," Trends in Cell Biology, vol. 17, no. 8, pp. 411-416, 2007.

[15] A. Eulalio, I. Behm-Ansmant, and E. Izaurralde, "P bodies: at the crossroads of post-transcriptional pathways," Nature Reviews Molecular Cell Biology, vol. 8, no. 1, pp. 9-22, 2007.

[16] R. Parker and U. Sheth, "P bodies and the control of mRNA translation and degradation," Molecular Cell, vol. 25, no. 5, pp. 635-646, 2007.

[17] J. G. Doench and P. A. Sharp, "Specificity of microRNA target selection in translational repression," Genes \& Development, vol. 18, no. 5, pp. 504-511, 2004.

[18] J. Brennecke, A. Stark, R. B. Russell, and S. M. Cohen, "Principles of microRNA-target recognition," PLoS Biology, vol. 3, no. 3, article e85, 2005.

[19] B. P. Lewis, C. B. Burge, and D. P. Bartel, "Conserved seed pairing, often flanked by adenosines, indicates that thousands of human genes are microRNA targets," Cell, vol. 120, no. 1, pp. 15-20, 2005.

[20] A. Grimson, K. K. Farh, W. K. Johnston, P. Garrett-Engele, L. P. Lim, and D. P. Bartel, "MicroRNA targeting specificity in mammals: determinants beyond seed pairing," Molecular Cell, vol. 27, no. 1, pp. 91-105, 2007.

[21] A. Esquela-Kerscher and F. J. Slack, "Oncomirs-microRNAs with a role in cancer," Nature Reviews Cancer, vol. 6, no. 4, pp. 259-269, 2006.

[22] D. P. Bartel, "MicroRNAs: genomics, biogenesis, mechanism, and function," Cell, vol. 116, no. 2, pp. 281-297, 2004.

[23] G. A. Calin, C. G. Liu, C. Sevignani et al., "MicroRNA profiling reveals distinct signatures in B cell chronic lymphocytic leukemias," Proceedings of the National Academy of Sciences of the United States of America, vol. 101, no. 32, pp. 1175511760, 2004.

[24] P. S. Eis, W. Tam, L. Sun et al., "Accumulation of miR-155 and BIC RNA in human B cell lymphomas," Proceedings of the National Academy of Sciences of the United States of America, vol. 102, no. 10, pp. 3627-3632, 2005.

[25] E. Barbarotto and G. A. Calin, "Potential therapeutic applications of miRNA-based technology in hematological malignancies," Current Pharmaceutical Design, vol. 14, no. 21, pp. 2040-2050, 2008.

[26] C. P. Arnold, R. Tan, B. Zhou et al., "MicroRNA programs in normal and aberrant stem and progenitor cells," Genome Research, vol. 21, no. 5, pp. 798-810, 2011.

[27] J. Lu, G. Getz, E. A. Miska et al., "MicroRNA expression profiles classify human cancers," Nature, vol. 435, no. 7043, pp. 834-838, 2005.

[28] R. M. O'Connell, D. S. Rao, A. A. Chaudhuri et al., "Sustained expression of microRNA-155 in hematopoietic stem cells causes a myeloproliferative disorder," Journal of Experimental Medicine, vol. 205, no. 3, pp. 585-594, 2008.

[29] Y. C. Han, C. Y. Park, G. Bhagat et al., "MicroRNA29a induces aberrant self-renewal capacity in hematopoietic progenitors, biased myeloid development, and acute myeloid leukemia," Journal of Experimental Medicine, vol. 207, no. 3, pp. 475-489, 2010.

[30] G. A. Calin, C. D. Dumitru, M. Shimizu et al., "Frequent deletions and down-regulation of micro-RNA genes miR15 and miR16 at 13q14 in chronic lymphocytic leukemia," Proceedings of the National Academy of Sciences of the United States of America, vol. 99, no. 24, pp. 15524-15529, 2002. 
[31] E. Salerno, B. J. Scaglione, F. D. Coffman et al., "Correcting miR-15a/16 genetic defect in New Zealand black mouse model of CLL enhances drug sensitivity," Molecular Cancer Therapeutics, vol. 8, no. 9, pp. 2684-2692, 2009.

[32] U. Klein, M. Lia, M. Crespo et al., "The DLEU2/miR-15a/161 cluster controls B cell proliferation and its deletion leads to chronic lymphocytic leukemia," Cancer Cell, vol. 17, no. 1, pp. 28-40, 2010.

[33] R. M. O'Connell, A. A. Chaudhuri, D. S. Rao, W. S. Gibson, A. B. Balazs, and D. Baltimore, "MicroRNAs enriched in hematopoietic stem cells differentially regulate long-term hematopoietic output," Proceedings of the National Academy of Sciences of the United States of America, vol. 107, no. 32, pp. 14235-14240, 2010.

[34] S. Costinean, N. Zanesi, Y. Pekarsky et al., "Pre-B cell proliferation and lymphoblastic leukemia/high-grade lymphoma in E $\mu$-miR155 transgenic mice," Proceedings of the National Academy of Sciences of the United States of America, vol. 103, no. 18, pp. 7024-7029, 2006.

[35] R. Liao, J. Sun, L. Zhang et al., "MicroRNAs play a role in the development of human hematopoietic stem cells," Journal of Cellular Biochemistry, vol. 104, no. 3, pp. 805-817, 2008.

[36] K. D. Taganov, M. P. Boldin, K. J. Chang, and D. Baltimore, "NF- $\kappa$ B-dependent induction of microRNA miR-146, an inhibitor targeted to signaling proteins of innate immune responses," Proceedings of the National Academy of Sciences of the United States of America, vol. 103, no. 33, pp. 1248112486, 2006.

[37] T. Ruggiero, M. Trabucchi, F. De Santa et al., "LPS induces $\mathrm{KH}$-type splicing regulatory protein-dependent processing of microRNA-155 precursors in macrophages," FASEB Journal, vol. 23, no. 9, pp. 2898-2908, 2009.

[38] M. Ceppi, P. M. Pereira, I. Dunand-Sauthier et al., "MicroRNA-155 modulates the interleukin-1 signaling pathway in activated human monocyte-derived dendritic cells," Proceedings of the National Academy of Sciences of the United States of America, vol. 106, no. 8, pp. 2735-2740, 2009.

[39] B. Tang, B. Xiao, Z. Liu et al., "Identification of MyD88 as a novel target of miR-155, involved in negative regulation of Helicobacter pylori-induced inflammation," FEBS Letters, vol. 584, no. 8, pp. 1481-1486, 2010.

[40] C. E. McCoy, F. J. Sheedy, J. E. Qualls et al., "IL-10 inhibits miR-155 induction by toll-like receptors," The Journal of Biological Chemistry, vol. 285, no. 27, pp. 20492-20498, 2010.

[41] B. S. Cobb, T. B. Nesterova, E. Thompson et al., "T cell lineage choice and differentiation in the absence of the RNase III enzyme dicer," Journal of Experimental Medicine, vol. 201, no. 9, pp. 1367-1373, 2005.

[42] S. A. Muljo, K. M. Ansel, C. Kanellopoulou, D. M. Livingston, A. Rao, and K. Rajewsky, "Aberrant T cell differentiation in the absence of dicer," Journal of Experimental Medicine, vol. 202, no. 2, pp. 261-269, 2005.

[43] S. B. Koralov, S. A. Muljo, G. R. Galler et al., "Dicer ablation affects antibody diversity and cell survival in the B lymphocyte lineage," Cell, vol. 132, no. 5, pp. 860-874, 2008.

[44] A. Rodriguez, E. Vigorito, S. Clare et al., "Requirement of bic/microRNA-155 for normal immune function," Science, vol. 316, no. 5824, pp. 608-611, 2007.

[45] T. H. Thai, D. P. Calado, S. Casola et al., "Regulation of the germinal center response by microRNA-155," Science, vol. 316, no. 5824, pp. 604-608, 2007.

[46] E. Vigorito, K. L. Perks, C. Abreu-Goodger et al., "MicroRNA-155 regulates the generation of immunoglobulin class-switched plasma cells," Immunity, vol. 27, no. 6, pp. 847-859, 2007.

[47] S. Kohlhaas, O. A. Garden, C. Scudamore, M. Turner, K. Okkenhaug, and E. Vigorito, "Cutting edge: the foxp3 target miR-155 contributes to the development of regulatory $\mathrm{T}$ cells1," Journal of Immunology, vol. 182, no. 5, pp. 2578-2582, 2009.

[48] T. Eystathioy, E. K. Chan, S. A. Tenenbaum, J. D. Keene, K. Griffith, and M. J. Fritzler, "A phosphorylated cytoplasmic autoantigen, GW182, associates with a unique population of human mRNAs within novel cytoplasmic speckles," Molecular Biology of the Cell, vol. 13, no. 4, pp. 1338-1351, 2002.

[49] R. A. Bhanji, T. Eystathioy, E. K. Chan, D. B. Bloch, and M. J. Fritzler, "Clinical and serological features of patients with autoantibodies to GW/P bodies," Clinical Immunology, vol. 125, no. 3, pp. 247-256, 2007.

[50] Y. Tang, X. Luo, H. Cui et al., "MicroRNA-146a contributes to abnormal activation of the type I interferon pathway in human lupus by targeting the key signaling proteins," Arthritis \& Rheumatism, vol. 60, no. 4, pp. 1065-1075, 2009.

[51] R. Dai, Y. Zhang, D. Khan et al., "Identification of a common lupus disease-associated microRNA expression pattern in three different murine models of lupus," PloS ONE, vol. 5, no. 12, article e14302, 2010.

[52] E. Tili, J. J. Michaille, D. Wernicke et al., "Mutator activity induced by microRNA-155 (miR-155) links inflammation and cancer," Proceedings of the National Academy of Sciences of the United States of America, vol. 108, no. 12, pp. 4908-4913, 2011.

[53] A. Ota, H. Tagawa, S. Karnan et al., "Identification and characterization of a novel gene, C13orf25, as a target for 13q31q32 amplification in malignant lymphoma," Cancer Research, vol. 64, no. 9, pp. 3087-3095, 2004.

[54] B. Zhang, X. Pan, G. P. Cobb, and T. A. Anderson, "microRNAs as oncogenes and tumor suppressors," Developmental Biology, vol. 302, no. 1, pp. 1-12, 2007.

[55] H. Tagawa and M. Seto, "A microRNA cluster as a target of genomic amplification in malignant lymphoma," Leukemia, vol. 19, no. 11, pp. 2013-2016, 2005.

[56] C. Xiao, L. Srinivasan, D. P. Calado et al., "Lymphoproliferative disease and autoimmunity in mice with increased miR17-92 expression in lymphocytes," Nature Immunology, vol. 9, no. 4, pp. 405-414, 2008.

[57] V. Kumar, A. K. Abbas, J. C. Aster, and S. L. Robbins, Robbins Basic Pathology, Elsevier Saunders, Philadelphia, Pa, USA, 9th edition, 2013.

[58] D. Löffler, K. Brocke-Heidrich, G. Pfeifer et al., "Interleukin6-dependent survival of multiple myeloma cells involves the Stat3-mediated induction of microRNA-21 through a highly conserved enhancer," Blood, vol. 110, no. 4, pp. 1330-1333, 2007.

[59] D. Ronchetti, M. Lionetti, L. Mosca et al., "An integrative genomic approach reveals coordinated expression of intronic miR-335, miR-342, and miR-561 with deregulated host genes in multiple myeloma," BMC Medical Genomics, vol. 1, article 37, 2008.

[60] F. Pichiorri, S. S. Suh, M. Ladetto et al., "MicroRNAs regulate critical genes associated with multiple myeloma pathogenesis," Proceedings of the National Academy of Sciences of the United States of America, vol. 105, no. 35, pp. 12885-12890, 2008.

[61] L. Chen, C. Li, R. Zhang et al., "MiR-17-92 cluster microRNAs confers tumorigenicity in multiple myeloma," Cancer Letters, vol. 309, no. 1, pp. 62-70, 2011. 
[62] A. M. Roccaro, A. Sacco, B. Thompson et al., "MicroRNAs $15 \mathrm{a}$ and 16 regulate tumor proliferation in multiple myeloma," Blood, vol. 113, no. 26, pp. 6669-6680, 2009.

[63] M. Lerner, M. Harada, J. Lovén et al., "DLEU2, frequently deleted in malignancy, functions as a critical host gene of the cell cycle inhibitory microRNAs miR-15a and miR-16-1," Experimental Cell Research, vol. 315, no. 17, pp. 2941-2952, 2009.

[64] M. Kumar, Z. Lu, A. A. Takwi et al., "Negative regulation of the tumor suppressor p53 gene by microRNAs," Oncogene, vol. 30, no. 7, pp. 843-853, 2011.

[65] F. Pichiorri, S. S. Suh, A. Rocci et al., "Downregulation of p53-inducible microRNAs 192, 194, and 215 impairs the p53/MDM2 autoregulatory loop in multiple myeloma development," Cancer Cell, vol. 18, no. 4, pp. 367-381, 2010.

[66] K. Y. Wong, C. C. So, F. Loong et al., "Epigenetic inactivation of the miR-124-1 in haematological malignancies," PLoS ONE, vol. 6, no. 4, article e19027, 2011.

[67] K. Y. Wong, R. Liang, C. C. So, D. Y. Jin, J. F. Costello, and C. S. Chim, "Epigenetic silencing of MIR203 in multiple myeloma," British Journal of Haematology, vol. 154, no. 5, pp. 569-578, 2011.

[68] Y. K. Zhang, H. Wang, Y. Leng et al., "Overexpression of microRNA-29b induces apoptosis of multiple myeloma cells through down regulating Mcl-1," Biochemical and Biophysical Research Communications, vol. 414, no. 1, pp. 233-239, 2011.

[69] V. J. Craig, S. B. Cogliatti, H. Rehrauer, T. Wündisch, and A. Müller, "Epigenetic silencing of microRNA-203 dysregulates ABL1 expression and drives helicobacter-associated gastric lymphomagenesis," Cancer Research, vol. 71, no. 10, pp. 3616-3624, 2011.

[70] J. Cai, X. Liu, J. Cheng et al., "MicroRNA-200 is commonly repressed in conjunctival MALT lymphoma, and targets cyclin E2," Graefe's Archive for Clinical and Experimental Ophthalmology, vol. 250, no. 4, pp. 523-531, 2012.

[71] M. Tomana, J. Novak, B. A. Julian, K. Matousovic, K. Konecny, and J. Mestecky, "Circulating immune complexes in IgA nephropathy consist of IgA1 with galactose-deficient hinge region and antiglycan antibodies," The Journal of Clinical Investigation, vol. 104, no. 1, pp. 73-81, 1999.

[72] G. Wang, B. C. Kwan, F. M. Lai, K. M. Chow, P. K. Li, and C. C. Szeto, "Elevated levels of miR-146a and miR-155 in kidney biopsy and urine from patients with IgA nephropathy," Disease Markers, vol. 30, no. 4, pp. 171-179, 2011.

[73] I. Bhatti, A. Lee, J. Lund, and M. Larvin, "Small RNA: a large contributor to carcinogenesis?" Journal of Gastrointestinal Surgery, vol. 13, no. 7, pp. 1379-1388, 2009.

[74] S. P. Nana-Sinkam and C. M. Croce, "MicroRNA in chronic lymphocytic leukemia: transitioning from laboratory-based investigation to clinical application," Cancer Genetics and Cytogenetics, vol. 203, no. 2, pp. 127-133, 2010.

[75] B. L. Betz and J. L. Hess, "Acute myeloid leukemia diagnosis in the 21st century," Archives of Pathology and Laboratory Medicine, vol. 134, no. 10, pp. 1427-1433, 2010.

[76] K. Mrózek, N. A. Heerema, and C. D. Bloomfield, "Cytogenetics in acute leukemia," Blood Reviews, vol. 18, no. 2, pp. 115-136, 2004.

[77] K. Mrózek, G. Marcucci, P. Paschka, S. P. Whitman, and C. D. Bloomfield, "Clinical relevance of mutations and geneexpression changes in adult acute myeloid leukemia with normal cytogenetics: are we ready for a prognostically prioritized molecular classification?" Blood, vol. 109, no. 2, pp. 431-448, 2007.
[78] G. Marcucci, K. Mrózek, and C. D. Bloomfield, "Molecular heterogeneity and prognostic biomarkers in adults with acute myeloid leukemia and normal cytogenetics," Current Opinion in Hematology, vol. 12, no. 1, pp. 68-75, 2005.

[79] A. Renneville, C. Roumier, V. Biggio et al., "Cooperating gene mutations in acute myeloid leukemia: a review of the literature," Leukemia, vol. 22, no. 5, pp. 915-931, 2008.

[80] S. Mi, J. Lu, M. Sun et al., "MicroRNA expression signatures accurately discriminate acute lymphoblastic leukemia from acute myeloid leukemia," Proceedings of the National Academy of Sciences of the United States of America, vol. 104, no. 50, pp. 19971-19976, 2007.

[81] Y. Wang, Z. Li, C. He et al., "MicroRNAs expression signatures are associated with lineage and survival in acute leukemias," Blood Cells, Molecules, and Diseases, vol. 44, no. 3, pp. 191-197, 2010.

[82] R. Garzon, S. Volinia, C. G. Liu et al., "MicroRNA signatures associated with cytogenetics and prognosis in acute myeloid leukemia," Blood, vol. 111, no. 6, pp. 3183-3189, 2008.

[83] S. M. Gao, J. Yang, C. Chen et al., "miR-15a/16-1 enhances retinoic acid-mediated differentiation of leukemic cells and is up-regulated by retinoic acid," Leukemia \& Lymphoma, vol. 52, no. 12, pp. 2365-2371, 2011.

[84] M. Jongen-Lavrencic, S. M. Sun, M. K. Dijkstra, P. J. Valk, and B. Löwenberg, "MicroRNA expression profiling in relation to the genetic heterogeneity of acute myeloid leukemia," Blood, vol. 111, no. 10, pp. 5078-5085, 2008.

[85] M. Alcalay, E. Tiacci, R. Bergomas et al., "Acute myeloid leukemia bearing cytoplasmic nucleophosmin (NPMc+ AML) shows a distinct gene expression profile characterized by up-regulation of genes involved in stem-cell maintenance," Blood, vol. 106, no. 3, pp. 899-902, 2005.

[86] S. Yekta, I. H. Shih, and D. P. Bartel, "MicroRNA-directed cleavage of HOXB8 mRNA," Science, vol. 304, no. 5670, pp. 594-596, 2004.

[87] R. Garzon, M. Garofalo, M. P. Martelli et al., "Distinctive microRNA signature of acute myeloid leukemia bearing cytoplasmic mutated nucleophosmin," Proceedings of the National Academy of Sciences of the United States of America, vol. 105, no. 10, pp. 3945-3950, 2008.

[88] S. P. Whitman, K. Maharry, M. D. Radmacher et al., "FLT3 internal tandem duplication associates with adverse outcome and gene- and microRNA-expression signatures in patients 60 years of age or older with primary cytogenetically normal acute myeloid leukemia: a cancer and leukemia group B study," Blood, vol. 116, no. 18, pp. 3622-3626, 2010.

[89] Z. Li, J. Lu, M. Sun et al., "Distinct microRNA expression profiles in acute myeloid leukemia with common translocations," Proceedings of the National Academy of Sciences of the United States of America, vol. 105, no. 40, pp. 15535-15540, 2008.

[90] A. Dixon-McIver, P. East, C. A. Mein et al., "Distinctive patterns of microRNA expression associated with karyotype in acute myeloid leukaemia," PLoS ONE, vol. 3, no. 5, article e2141, 2008.

[91] X. Wang, E. Gocek, C. G. Liu, and G. P. Studzinski, "MicroRNAs181 regulate the expression of p27Kip1 in human myeloid leukemia cells induced to differentiate by 1,25dihydroxyvitamin D3," Cell Cycle, vol. 8, no. 5, pp. 736-741, 2009.

[92] Y. D. Zhu, L. Wang, C. Sun et al., "Distinctive microRNA signature is associated with the diagnosis and prognosis of acute leukemia," Medical Oncology. In press. 
[93] M. Hallek, B. D. Cheson, D. Catovsky et al., "Guidelines for the diagnosis and treatment of chronic lymphocytic leukemia: a report from the international workshop on chronic lymphocytic leukemia updating the National Cancer Institute-working group 1996 guidelines," Blood, vol. 111, no. 12, pp. 5446-5456, 2008.

[94] J. G. Gribben and S. O’Brien, "Update on therapy of chronic lymphocytic leukemia," Journal of Clinical Oncology, vol. 29, no. 5, pp. 544-550, 2011.

[95] H. Döhner, S. Stilgenbauer, A. Benner et al., "Genomic aberrations and survival in chronic lymphocytic leukemia," The New England Journal of Medicine, vol. 343, no. 26, pp. 1910 1916, 2000.

[96] G. A. Calin and C. M. Croce, "Genomics of chronic lymphocytic leukemia microRNAs as new players with clinical significance," Seminars in Oncology, vol. 33, no. 2, pp. 167$173,2006$.

[97] E. Salerno, B. J. Scaglione, F. D. Coffman et al., "Correcting miR-15a/16 genetic defect in New Zealand black mouse model of CLL enhances drug sensitivity," Molecular Cancer Therapeutics, vol. 8, no. 9, pp. 2684-2692, 2009.

[98] A. Cimmino, G. A. Calin, M. Fabbri et al., "miR-15 and miR16 induce apoptosis by targeting BCL2," Proceedings of the National Academy of Sciences of the United States of America, vol. 102, no. 39, pp. 13944-13949, 2005.

[99] E. S. Raveche, E. Salerno, B. J. Scaglione et al., "Abnormal microRNA-16 locus with synteny to human 13q14 linked to CLL in NZB mice," Blood, vol. 109, no. 12, pp. 5079-5086, 2007.

[100] Y. Pekarsky, U. Santanam, A. Cimmino et al., "Tcl1 expression in chronic lymphocytic leukemia is regulated by miR-29 and miR-181," Cancer Research, vol. 66, no. 24, pp. 1159011593, 2006

[101] U. Santanam, N. Zanesi, A. Efanov et al., "Chronic lymphocytic leukemia modeled in mouse by targeted miR-29 expression," Proceedings of the National Academy of Sciences of the United States of America, vol. 107, no. 27, pp. 12210$12215,2010$.

[102] M. Fabbri, A. Bottoni, M. Shimizu et al., "Association of a microRNA/TP53 feedback circuitry with pathogenesis and outcome of b-cell chronic lymphocytic leukemia," Journal of the American Medical Association, vol. 305, no. 1, pp. 59-67, 2011.

[103] G. Zauli, R. Voltan, M. G. di Iasio et al., "miR-34a induces the downregulation of both E2F1 and B-Myb oncogenes in leukemic cells," Clinical Cancer Research, vol. 17, no. 9, pp. 2712-2724, 2011.

[104] V. Fulci, S. Chiaretti, M. Goldoni et al., "Quantitative technologies establish a novel microRNA profile of chronic lymphocytic leukemia," Blood, vol. 109, no. 11, pp. 4944-4951, 2007.

[105] K. Vargova, N. Curik, P. Burda et al., "MYB transcriptionally regulates the miR-155 host gene in chronic lymphocytic leukemia," Blood, vol. 117, no. 14, pp. 3816-3825, 2011.

[106] C. H. Lawrie, S. Gal, H. M. Dunlop et al., "Detection of elevated levels of tumour-associated microRNAs in serum of patients with diffuse large B-cell lymphoma," British Journal of Haematology, vol. 141, no. 5, pp. 672-675, 2008.

[107] X. Chen, Y. Ba, L. Ma et al., "Characterization of microRNAs in serum: a novel class of biomarkers for diagnosis of cancer and other diseases," Cell Research, vol. 18, no. 10, pp. 9971006, 2008.
[108] E. Moussay, K. Wang, J. H. Cho et al., "MicroRNA as biomarkers and regulators in B-cell chronic lymphocytic leukemia," Proceedings of the National Academy of Sciences of the United States of America, vol. 108, no. 16, pp. 6573-6578, 2011.

[109] J. R. Finnerty, W. X. Wang, S. S. Hébert, B. R. Wilfred, G. Mao, and P. T. Nelson, "The miR-15/107 group of microRNA genes: evolutionary biology, cellular functions, and roles in human diseases," Journal of Molecular Biology, vol. 402, no. 3, pp. 491-509, 2010.

[110] P. T. Nelson, W. X. Wang, G. Mao et al., "Specific sequence determinants of miR-15/107 microRNA gene group targets," Nucleic Acids Research, vol. 39, no. 18, pp. 8163-8172, 2011.

[111] J. Pothof, N. S. Verkaik, W. van Ijcken et al., "MicroRNAmediated gene silencing modulates the UV-induced DNAdamage response," EMBO Journal, vol. 28, no. 14, pp. 20902099, 2009.

[112] B. Zhang and X. Pan, "RDX induces aberrant expression of microRNAs in mouse brain and liver," Environmental Health Perspectives, vol. 117, no. 2, pp. 231-240, 2009.

[113] J. B. Redell, Y. Liu, and P. K. Dash, “Traumatic brain injury alters expression of hippocampal microRNAs: potential regulators of multiple pathophysiological processes," Journal of Neuroscience Research, vol. 87, no. 6, pp. 1435-1448, 2009.

[114] R. Kulshreshtha, M. Ferracin, S. E. Wojcik et al., "A microRNA signature of hypoxia," Molecular and Cellular Biology, vol. 27, no. 5, pp. 1859-1867, 2007.

[115] K. J. Yin, Z. Deng, M. Hamblin et al., "Peroxisome proliferator-activated receptor $\delta$ regulation of miR-15a in ischemia-induced cerebral vascular endothelial injury," Journal of Neuroscience, vol. 30, no. 18, pp. 6398-6408, 2010.

[116] T. C. Chang, D. Yu, Y. S. Lee et al., "Widespread microRNA repression by Myc contributes to tumorigenesis," Nature Genetics, vol. 40, no. 1, pp. 43-50, 2008.

[117] X. Zhang, X. Chen, J. Lin et al., "Myc represses miR-15a/miR16-1 expression through recruitment of HDAC3 in mantle cell and other non-Hodgkin B-cell lymphomas," Oncogene, vol. 31, no. 24, pp. 3002-3008, 2012.

[118] G. A. Calin, A. Cimmino, M. Fabbri et al., "MiR-15a and miR-16-1 cluster functions in human leukemia," Proceedings of the National Academy of Sciences of the United States of America, vol. 105, no. 13, pp. 5166-5171, 2008.

[119] Y. Takahashi, A. R. Forrest, E. Maeno, T. Hashimoto, C. O. Daub, and J. Yasuda, "MiR-107 and MiR-185 can induce cell cycle arrest in human non small cell lung cancer cell lines," PLoS ONE, vol. 4, no. 8, article e6677, 2009.

[120] R. G. Wickremasinghe, A. G. Prentice, and A. J. Steele, "P53 and notch signaling in chronic lymphocytic leukemia: clues to identifying novel therapeutic strategies," Leukemia, vol. 25, pp. 1400-1407, 2011.

[121] A. Albihn, J. I. Johnsen, and M. A. Henriksson, "MYC in oncogenesis and as a target for cancer therapies," Advances in Cancer Research, vol. 107, pp. 163-224, 2010.

[122] G. A. Calin, M. Ferracin, A. Cimmino et al., "A microRNA signature associated with prognosis and progression in chronic lymphocytic leukemia," The New England Journal of Medicine, vol. 353, no. 17, pp. 1793-1801, 2005.

[123] Y. Guo, Z. Chen, L. Zhang et al., "Distinctive microRNA profiles relating to patient survival in esophageal squamous cell carcinoma," Cancer Research, vol. 68, no. 1, pp. 26-33, 2008.

[124] H. M. Heneghan, N. Miller, R. Kelly, J. Newell, and M. J. Kerin, "Systemic miRNA-195 differentiates breast cancer from other malignancies and is a potential biomarker for 
detecting noninvasive and early stage disease," Oncologist, vol. 15, no. 7, pp. 673-682, 2010.

[125] D. Li, Y. Zhao, C. Liu et al., "Analysis of MiR-195 and MiR497 expression, regulation and role in breast cancer," Clinical Cancer Research, vol. 17, no. 7, pp. 1722-1730, 2011.

[126] A. Hutloff, K. Büchner, K. Reiter et al., "Involvement of inducible costimulator in the exaggerated memory B cell and plasma cell generation in systemic lupus erythematosus," Arthritis \& Rheumatism, vol. 50, no. 10, pp. 3211-3220, 2004.

[127] S. Lacotte, H. Dumortier, M. Décossas, J. P. Briand, and S. Muller, "Identification of new pathogenic players in lupus: autoantibody-secreting cells are present in nephritic kidneys of (NZBxNZW)F1 mice," Journal of Immunology, vol. 184, no. 7, pp. 3937-3945, 2010.

[128] G. Q. Daley, “Towards the generation of patient-specific pluripotent stem cells for combined gene and cell therapy of hematologic disorders," Hematology, vol. 2007, no. 1, pp. 1722, 2007.

[129] S. K. Mallanna and A. Rizzino, "Emerging roles of microRNAs in the control of embryonic stem cells and the generation of induced pluripotent stem cells," Developmental Biology, vol. 344, no. 1, pp. 16-25, 2010.

[130] F. Anokye-Danso, C. M. Trivedi, D. Juhr et al., "Highly efficient miRNA-mediated reprogramming of mouse and human somatic cells to pluripotency," Cell Stem Cell, vol. 8, no. 4, pp. 376-388, 2011.

[131] A. Marson, S. S. Levine, M. F. Cole et al., "Connecting microRNA genes to the core transcriptional regulatory circuitry of embryonic stem cells," Cell, vol. 134, no. 3, pp. 521-533, 2008.

[132] M. Sachdeva, S. Zhu, F. Wu et al., "P53 represses c-Myc through induction of the tumor suppressor miR-145," Proceedings of the National Academy of Sciences of the United States of America, vol. 106, no. 9, pp. 3207-3212, 2009.

[133] S. Guo, J. Lu, R. Schlanger et al., "MicroRNA miR-125a controls hematopoietic stem cell number," Proceedings of the National Academy of Sciences of the United States of America, vol. 107, no. 32, pp. 14229-14234, 2010.

[134] U. Bissels, A. Bosio, and W. Wagner, "MicroRNAs are shaping the hematopoietic landscape," Haematologica, vol. 97, no. 2, pp. 160-167, 2012.

[135] S. Careccia, S. Mainardi, A. Pelosi et al., "A restricted signature of miRNAs distinguishes APL blasts from normal promyelocytes," Oncogene, vol. 28, no. 45, pp. 4034-4040, 2009.

[136] S. Kasar, E. Salerno, Y. Yuan et al., "Systemic in vivo lentiviral delivery of miR-15a/16 reduces malignancy in the NZB de novo mouse model of chronic lymphocytic leukemia," Genes \& Immunity, vol. 13, no. 2, pp. 109-119, 2011.

[137] D. L. Zanette, F. Rivadavia, G. A. Molfetta et al., "miRNA expression profiles in chronic lymphocytic and acute lymphocytic leukemia," Brazilian Journal of Medical and Biological Research, vol. 40, no. 11, pp. 1435-1440, 2007.

[138] C. P. Pallasch, M. Patz, J. P. Yoon et al., "miRNA deregulation by epigenetic silencing disrupts suppression of the oncogene PLAG1 in chronic lymphocytic leukemia," Blood, vol. 114, no. 15, pp. 3255-3264, 2009. 


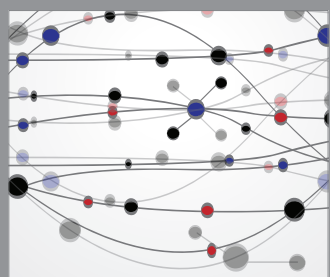

The Scientific World Journal
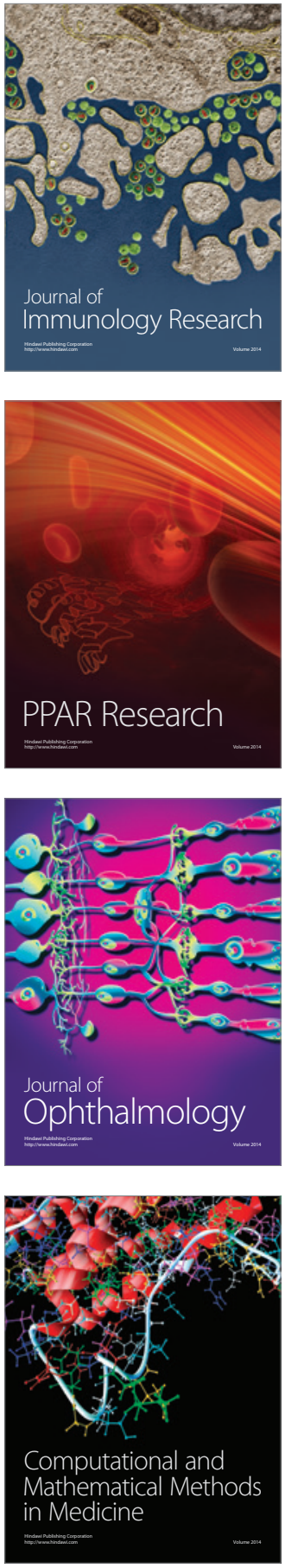

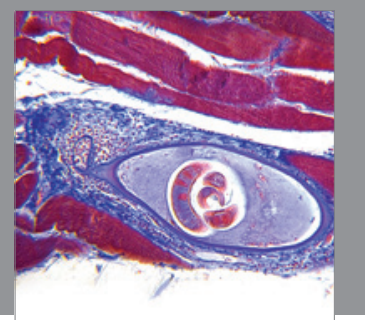

Gastroenterology

Research and Practice
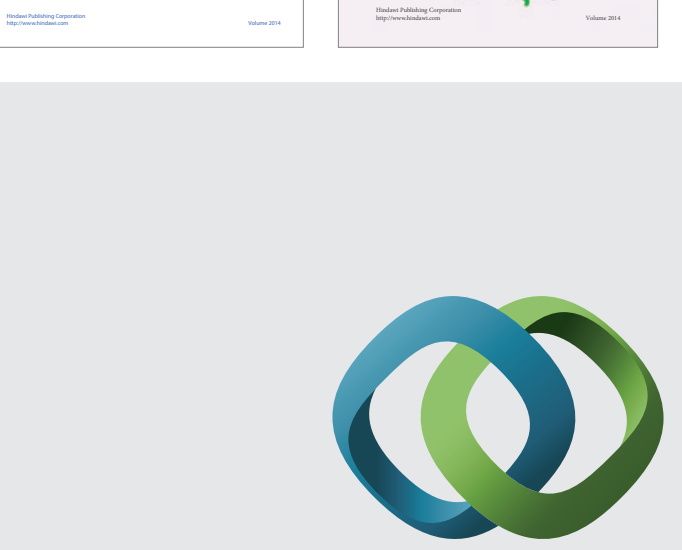

\section{Hindawi}

Submit your manuscripts at

http://www.hindawi.com
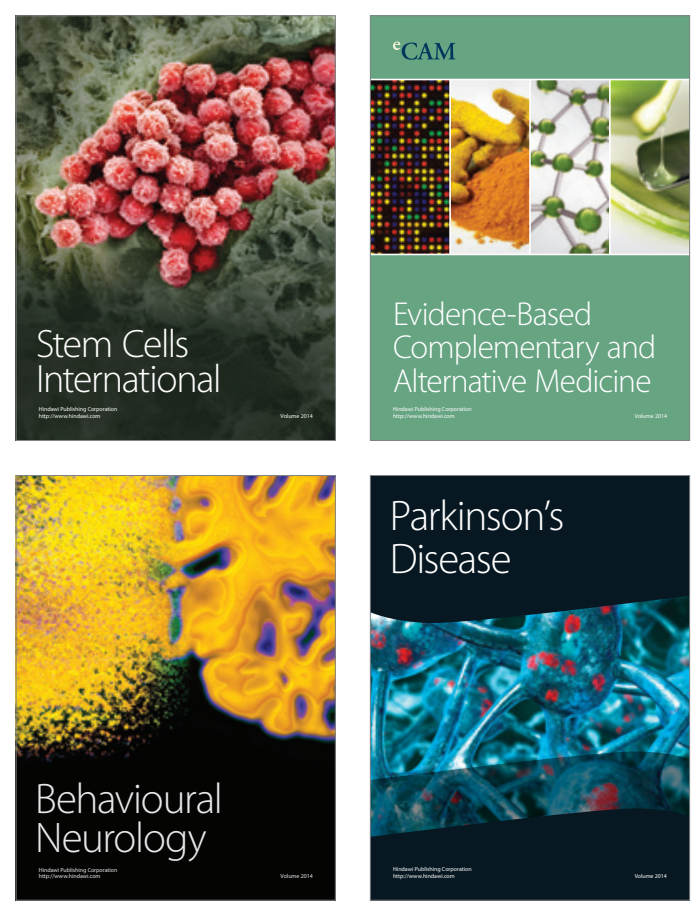

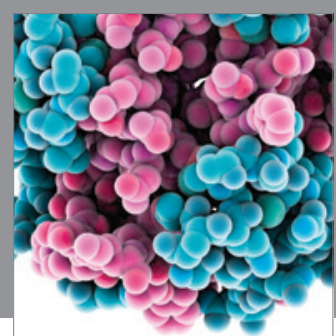

Journal of
Diabetes Research

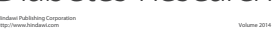

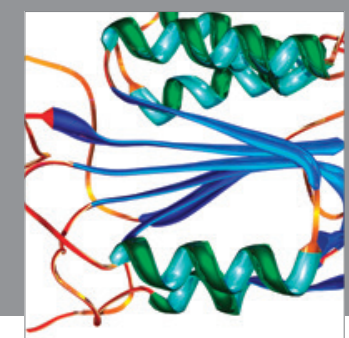

Disease Markers
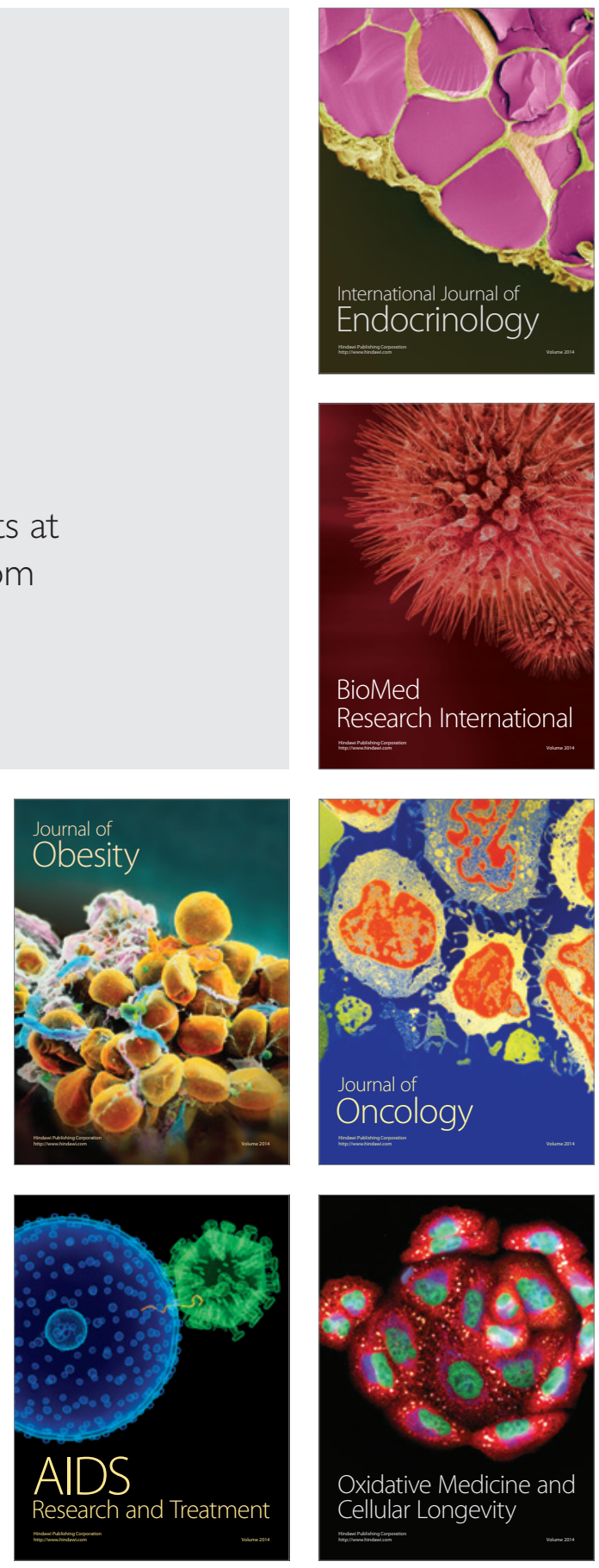